\title{
Developmental Care: assistance of nurses from Neonatal Intensive Care Units
}

\author{
Cuidado Desenvolvimental: assistência de enfermeiros de Unidade de Terapia Intensiva Neonatal \\ Cuidado de desarrollo: asistencia de los enfermeros de Unidad de Terapia Intensiva Neonatal
}

\section{Bruna de Souza Lima Marski', Beatriz Castanheira Facio', Sueli Mutsumi Tsukuda Ichisato", Patricia Carla de Souza Della Barba', Monika Wernet'}

' Universidade Federal de São Carlos. São Carlos, São Paulo, Brazil. "Universidade Estadual de Maringá. Maringá, Paraná, Brazil.

How to cite this article:

Marski BSL, Facio BC, Ichisato SMT, Barba PCSD, Wernet M. Developmental Care: assistance of nurses from Neonatal Intensive Care Units. Rev Bras Enferm [Internet]. 2018;71(Suppl 6):2758-66. [Thematic Issue: Good practices in the care process as the centrality of the Nursing] DOI: http://dx.doi.org/10.1590/0034-7167-2017-0912

Submission: 01-10-2018 Approval: 07-20-2018

\begin{abstract}
Objective: to analyze the Developmental Care in nursing care for Newborns in critical Neonatal Intensive Care Units. Method: a qualitative study with 11 nurses from Neonatal Intensive Care Units of a city in the State of São Paulo countryside, based on the Developmental Care. Data collection was based on non-participant observation, documentary research in medical records and semi-structured interviews. The Symbolic Interactionism was adopted as theoretical framework, and the Bardin Content Analysis, as method of analysis. Results: nurses have knowledge about Developmental Care; however, there are dissonances with doing them. The analysis is presented from two thematic categories: "Nurses' performance in the Developmental Care" and "Nurse, Family and Developmental Care". Final considerations: it is necessary to encourage reflections on the care of nurses regarding Developmental Care, and to foster sensitivity and perception in relation to the executed and registered.
\end{abstract}

Descriptors: Neonatal Intensive Care Units; Growth and Development; Nursing Care; Neonatal Nursing; Premature Newborn.

\section{RESUMO}

Objetivo: analisar o Cuidado Desenvolvimental na assistência de enfermeiros ao Recém-Nascido crítico, em Unidade de Terapia Intensiva Neonatal. Método: estudo qualitativo com 11 enfermeiros de Unidades de Terapia Intensiva Neonatal de um município do interior paulista que teve como base conceitual o Cuidado Desenvolvimental. A coleta de dados ocorreu a partir da observação não participante, pesquisa documental em prontuários e entrevista semiestruturada. O Interacionismo Simbólico foi adotado como referencial teórico, e a Análise de Conteúdo de Bardin, como método de análise. Resultados: os enfermeiros detêm conhecimento acerca do Cuidado Desenvolvimental, contudo, há dissonâncias com o fazer dos mesmos. A análise está apresentada a partir de duas categorias temáticas: "Cuidado Desenvolvimental na atuação do enfermeiro" e "Enfermeiro, família e Cuidado Desenvolvimental". Considerações finais: é necessário avivar reflexões sobre a assistência do enfermeiro quanto ao Cuidado Desenvolvimental, e fomentar sensibilidade e percepção em relação ao executado e registrado.

Descritores: Unidades de Terapia Intensiva Neonatal; Crescimento e Desenvolvimento; Cuidados de Enfermagem; Enfermagem Neonatal; Recém-Nascido Prematuro.

\section{RESUMEN}

Objetivo: analizar el cuidado de desarrollo en la asistencia de los enfermeros al Recién Nacido crítico, en Unidad de Terapia Intensiva Neonatal. Método: estudio cualitativo con 11 enfermeros de Unidades de Terapia Intensiva Neonatal de un municipio del interior paulista que tuvo como base conceptual el cuidado de desarrollo. La recolección de datos ocurrió a partir de la observación no participante, investigación documental en prontuarios y entrevista semiestructurada. El Interaccionismo Simbólico fue adoptado como referencial teórico, y el Análisis de Contenido de Bardin, como método de análisis. Resultados: los enfermeros poseen conocimiento acerca del Cuidado de Desarrollo; sin embargo, hay disonancias con el hacer de los mismos. El análisis se presenta a partir de dos categorías temáticas: "Cuidado de Desarrollo en la actuación del enfermero" y 
"Enfermero, familia y Cuidado de Desarrollo". Consideraciones finales: es necesario avivar reflexiones sobre la asistencia del enfermero en cuanto al Cuidado de Desarrollo y fomentar sensibilidad y percepción en relación al ejecutado y registrado.

Descriptores: Unidades de Terapia Intensiva Neonatal; Crecimiento y Desarrollo; Cuidados de Enfermería; Enfermería Neonatal; Recién Nacido Prematuro.

\section{CORRESPNDING AUTHOR Bruna de Souza Lima Marski E-mail: bmarski@gmail.com}

\section{INTRODUCTION}

In 2011 , about $9.8 \%$ of the $2,913,160$ births registered in Brazil were premature ${ }^{(1)}$. These Newborns (NB), due to prematurity, are usually referred to the Neonatal Intensive Care Unit $(\mathrm{NICU})^{(2)}$. Endowed with high technology and a massive supply of care, the NICU has a dual character since it favors clinical stability and survival(2) of premature newborns, while at the same time subjecting them to damages ${ }^{(3-4)}$. One of the factors that makes them vulnerable is their insufficient capacity for selfregulation, due to the high sensorial loads experienced in this context $^{(3)}$, mainly due to the effects of interventions performed without adequate measures of pain management ${ }^{(5)}$, luminosity and noise, allied to care protocols that disregard sleep and rest issues, generating stress and discomfort to the premature. Such context may imply an increased risk of abnormal brain maturation $^{(4)}$ and constitutes a morbidity factor ${ }^{(2)}$.

The philosophy of Developmental Care is anchored in protecting the overall development of the newborn when it gives special attention to its behavior, preservation of its energy and modulation capacity ${ }^{(3)}$. The Neonatal Individualized Care and Assessment Program (NIDCAP) ${ }^{(6)}$, a program developed by Heidelise Als in 1982, is a landmark in the use of this philosophy of care, inspiring other realities. The practice of NICU that adopts the precepts of the NIDCAP seeks to minimize noise and lightness, to handle the contiguous and clustered newborn, respect the newborn's biological clock/wakefulness and sleep states, and value presence, support and collaborative participation of the family ${ }^{(3,6)}$.

In the NICU, the nurse assumes the role of care manager and assistance to NBs and emerges as strategic for the provision of a qualified, humanized and comprehensive care to them ${ }^{(3)}$. Such care should be respectful and protective to cerebral peculiarities of the Newborn ${ }^{(3)}$. This implies that the NICU team of professionals, including nurses, explicitly assume the philosophy of Developmental Care (DC) in care $^{(7)}$, with commitment to contribute to neurobehavioral development potential of each $\mathrm{NB}$, in an integrated and collaborative way with his/her family ${ }^{(3)}$.

This study is justified by the aforementioned, as well as by considering the assumptions evidenced in the National Agenda of Priorities in Health Research (NAPHR) in relation to determinants of the child's life condition and development ${ }^{(8)}$. There is the question: "How do NICU nurses incorporate Developmental Care into their critical NB care?".

\section{OBJECTIVE}

To analyze the Developmental Care in the assistance of nurses to the critical NB in NICU.

\section{METHOD}

\section{Ethical aspects}

The study was analyzed and approved by the Human Research Ethics Committee of the Universidade Federal de São Carlos (UFSCar). In order to preserve the anonymity of the nurses, it was decided not to describe the participants' details and to assign each one the letter $\mathrm{N}$, followed by Arabic numerals from 1 to 11 , referring to the order in which they were interviewed.

\section{Theoretical framework}

Symbolic Interactionism has been adopted as a theoretical framework that focuses on appreciating and understanding how individuals interact with social objects and process individual and collective behaviors ${ }^{(9)}$.

\section{Type of study}

It is a field research, documentary and qualitative, that had Developmental Care as a conceptual basis. This philosophy of care is intended to minimize the stress generated by the intensive care setting and to avoid short and long-term complications of critical NBs and their family ${ }^{(10)}$. In this sense, it assumes a structured assistance that supports, guides and encourages the organization of development, with a view to identifying and acting on its physical, emotional and psychological frailties ${ }^{(10)}$. In addition to reducing deleterious impacts on neurodevelopment, length of hospital stay and use of mechanical ventilation, as well as favoring weight gain and increasing parental involvement in the care of the child ${ }^{(10)}$.

\section{Study setting and methodological procedures}

The study was carried out in a city in São Paulo State, with a live birth rate of 3,812 in 2015 , of which $10.2 \%$ were premature $^{(11)}$. This municipality has two Neonatal Intensive Care Units, one located in a philanthropic institution and that develops care related to the Supplementary System and the Brazilian Unified Health System (SUS- Sistema Único de Saúde), and the other with care by the supplementary and private system. The two units together total 22 beds, of which 14 are in the philanthropic institution and eight in the private one. The approximate ratio of nurses per bed was 1:7, and NICU occupancy rates for the data collection period of this study were $60 \%$ and $50 \%$, respectively.

\section{Data source}

Sixteen nurses composed the NICU record at the time of the study invitation. The inclusion criterion for participation was to be a nurse working in one of the aforementioned NICUs throughout the period of data collection. Nurses who were absent during the data collection period were excluded for the following reasons: one was on maternity leave, one on vacation, 
two left their positions in the NICU throughout the study and one for being an active member of the research group to which this study is linked. Thus, eleven nurses integrated the study.

\section{Collection and data organization}

We chose three strategies of data collection: non-participant observation, semi-structured interview and documentary research (NB record). The observation period comprised the first stage of data collection and occurred from September 9 to October 10, 2016, in the two settings already mentioned. Eleven nurses were observed individually, during two twelve-hour shifts, by the same researcher. Field notes were made during the same period, in order to record observations for later analysis. Data was collected from the records of nurses in medical records of $\mathrm{NB}$ at a different time from observation, but during the period from September 9 to October 10, 2016. The records of the nurses in a notebook designated for this purpose were fully transcribed. At the end of the observation and documentary research (search the medical records), the individual interview with the eleven nurses was carried out, which was triggered with the following proposal: "Record in writing how you would complete the sentence: For me, Developmental Care is...". Next, and from the one registered by each interviewed nurse, the interview began to explore the concept of Developmental Care, which actions were developed as a practice consistent with this philosophy of care, obstacles and facilities for the execution of a practice aligned with the precepts of the DC. All interviews, whose average duration was 30 minutes, were recorded in audio and transcribed in full.

\section{Data analysis}

The empirical data, in the form of texts, derived from the three data collection strategies, suffered the analytical processes advocated by content analysis in the thematic modality ${ }^{(12)}$. The process involved three steps: (1) pre-analysis; (2) exploration of the material, in order to codify and classify the empirical material, and (3) treatment of the results obtained and interpretation, with elaboration of the categories ${ }^{(12)}$. Two thematic categories will be presented in this study: "Nurses' performance in the Developmental Care" and "Nurse, Family and Developmental Care".

\section{RESULTS}

Eleven nurses, ten women and one man, aged between 25 and 44 years with training time of two to eight years participated in this study. The period of performance in NICU ranged from two months to seven years. Seven nurses were specialists in Neonatal Nursing.

\section{Thematic category: Nurses' performance in the Develop- mental Care}

The nurses were exposed to have knowledge about the DC and a certain desire to incorporate it in a more intense and broader way in their assistance to the NB, but they expressed power relations as restrictors, suggesting a restriction of freedom and autonomy for the incorporation of protective actions of neurobehavioral development.
But if we thinking about development part in care and development ... I think it has to do with the development of the child himself/herself. And that's why I include the motor function, the affective part, the social part, right? So, for example, calming the baby, right? Or put the baby on the lap of the mother, which is something that we do not do much here, but that I think it tends to improve, right? A more comfortable positioning that will not disrupt the movement in the future. (N11)

[...] then, look [laughs] some things I would like to do differently, but it does not depend on people, this is a medical issue, right ... we are submissive, the [Nursing] class, there is no way, depending on what is happening, we try to do our best, but there are things that only depends on their response, right? And sometimes it's not the way we wanted it, right? (N3)

They found an intimate relationship between Developmental Care and humanization, highlighting the relevance of appreciating the singularity of each NB, its demands and needs. They reported investments in physical proximity to the premature, with surveillance and recognition of him/her as a subject in the process of development. Derived from this, they emphasized the responsibility of nurses to develop actions with the environment and the team, with a view to minimizing the supply of harmful stimuli to the NB.

Being present by the newborn's side, not to leave, is, not to see the patient as another one, take care as if he/she were unique, a care with the employee, to take the lead, do not leave the patient alone, do not leave the environment abandoned. All the care relevant to that case. I do everything that is up to me. I think this way I'm promoting the development. (N7)

We [Nursing team] try to minimize the stimuli that within an ICU there are many stimuli, in a very big, very aggressive way. It is the nurse's job to watch. (N1)

Despite the verbalizations in this direction, the observed assistance denoted a strong anchorage in a routine that was almost pre-established and constantly replicated. The nurse's attention was more directed to the offer and operation of technological devices to support life and to the performance or monitoring of care activities, centered on food, hygiene, vital signs control and physiological eliminations. In this routine, the records revealed a common, almost watertight structure.

In the analysis of the records, of this and the others that I have been developing, they bring the same structural pattern in the Nursing evolutions, informing the days of the premature life, the daily weight with gains or losses, the type of bed in which premature was, use of assistive technologies, with predominance of information related to phototherapy; oxygen therapy and resources for the diet supply. The notes point to the current situation of the premature newborn and the progression or regression of the picture. They describe the use of drugs and the route of their administration. The physical examination described occurs in a cephalocaudal trend manner, with emphasis on the cardiopulmonary and gastrointestinal aspects. To conclude the evolution, information 
regarding physiological eliminations of the last 24 hours is presented. At different times of this record, materials used in procedures are listed in the private institution. (research note)

From the observation of the daily care of the NICU, we add to this context not always checked nursing prescriptions by the Nursing team and, according to participants, often checked without even being read. The records in the medical records did not show prescriptions that included attention or consideration to peculiarities of the NB, perhaps of his/her family.

The accomplishment of nursing prescription occurred through a computerized system, in which were given options of activities to be developed based on the selected Nursing diagnoses. Thus, specific care was prescribed, but not necessarily unique to each patient or based on the Developmental Care and its precepts. In addition, they predominantly kept a tone of evaluation of the evidence that denied the risk raised. (field note - observation)

In some situations, the nurses explained their perception and concern in welcoming the Newborn in its singularity. However, such movements and information contained therein were limited to oral communication between those involved, without taking place as records of medical records or allowing access through the shift between shifts of professionals.

I observe that the nurse, when perceiving the technique of Nursing to approach the incubator to proceed to the corporal hygiene of the $N B$, mentions that hygiene process should be fast and speaks "It has to be a Czech bath [term that embraces the idea of fast and superficial], because things are difficult [referring to the thermal instability of the NB]. However, there was no record in the records of how he behaved in the bath, and the information regarding this procedure was not mentioned in the duty shift. (field note - observation)

Regarding the concerns related to the DC, nurses reported investments to provide a less damaging and more welcoming environment to the NB, when they emphasized bed accommodation, noise, light and handling. They emphasized efforts to sensitize and guide the nursing team, especially the noise caused by the professionals' speech and the relevance of respecting the agreed period for NB sleep. In this aspect, there was congruence between interviews and observations developed.

[...] letting sleep for the child's development is paramount! And then I always say "the night does not have to be all the lights on, let's sing it down, let's laugh lower, let's talk lower." Because there are beings in need of this rest time for both body intellectual and moral development. (N8)

Paradoxically, the use of the dome of the incubator to support objects and execution of actions promoting noise was very practiced, although the incubators of the two Neonatal Intensive Care Units had in its composition the auxiliary tray for support.

It was observed that the incubator's dome as support was frequently adopted in this work as support of objects used in the assistance and procedures by all of the assistance team [doctors, nurses and nursing technicians]. The nurses seemed not to be bothered or surprised by this attitude, conceived as usual, but they showed concern with the alarms of the appliances, responding to them promptly. (field note- observation)

They mentioned identifying positive evidence in the reduction of NB handling, such as weight gain and the longer duration and quality of sleep, referring to guide the Nursing team about this care. It was perceived in the speeches that this is an aspect that draws the attention of the nurse, longitudinally. Considering the understanding they have about the DC, they pointed out and exemplified in the interview actions that they practiced in their daily lives, emphasizing: nests and interventions with the positioning with preference for flexor posture and attention to the comfort of the NB in position; use of soft touch in handlings; efforts to reduce harmful stimuli, and to minimize and treat pain. They justified that these actions favor the development of the $\mathrm{NB}$, both neurological and motor, and bring reflexes in adult life.

The issue of positioning, the nest, which I think is something that will still get into the discussion here, that will still have training, everything. But overall, [...] babies are poorly positioned here, right? So I think this, and, it is part of our care too, because it is something that will reflect on the baby's motor development, pain, [...] anyway, right? Baby that is not well positioned and consequently will have some problem of motor development later. Physical motor, right? (N5)

It draws attention as nests are always spotless. In performing painful procedures, the nursing team and the nurses seem to be actually reflecting whether comfort is being provided in the positioning of the premature. (field note - observation)

Although most understood the harm of excessive handling and claimed to perform measures that promote relaxation, it was customary to observe careful, but disjointed, sequential, and constant handling (three to four times with a maximum interval of five minutes) to accomplish prospective activities.

Examine a NB, with explicit affection in handling. Then he does evolution and checks exams. The person divides this function with the nurse in training, when there were situations in which they examined and handled the same NB three to four times in a short period of time, less than 5 minutes. In the conversation between them, neither made any comment about this fact, denoting being habitual comings and goings to premature newborns to fulfill activities prospected to them, with no apparent criticism about the unraveling in the handling accomplished. (field note- observation)

Regarding pain, there was a greater connection between the verbalized and the effective in the nurse's care, such as restraint, winding with a view to the reorganization of the neonate, and the provision of non-nutritive sucking during and after painful procedures. However, records were either incipient or nonexistent in this regard.

However, there was a situation in which the nurse's speech was in a pleasant tone with a NB that was sharply shaken: "What a brave, [NB's name]! Why are you so angry like that? Let's 
cover!". Then the oxygen saturation dropped and the nurse got up from the counter where he was, turned off the alarm and offered non-nutritive suction, because until that moment the baby had not stopped crying. (field note- observation)

The Kangaroo Mother Care (KMC) is another resource that was verbally cited for pain relief, however no actions were observed in this direction.

Oh, the Kangaroo Mother Care is good, right, feel the heat, in the moment of colic, in the pain. It calms down. I like to use. (N9)

\section{Thematic category: Nurse, Family and Developmental Care}

The family was identified as an essential and inseparable element in the care of the NICU, especially for its representativeness for NB's well-being, development and health. Thus, welcoming the family was verbalized as inherent to the DC and the responsibility of the nurse. The precept of humanization in health was conceived as an aspect that contributed to the openness and inclusion effort. With this, they mentioned encouragement to take risks, such as putting the NB tube in the lap of the mother or adjust visiting times.

The issue of humanization, letting the mothers stay inside. In my other job I only stayed when I was breastfeeding, not here, there is a child who does not grab the breast, but the mother stays here all day, with the baby on her lap, we teach care, and then opened the doors. The parents are so close together, they let their mothers in, they stay with the baby, they have food for their mothers, they have no other job here, they can stay here all day, they have coffee, lunch, there is everything ... so I guess is very different and very good, good for health, for the same development. (N3)

They accomplished the search of approaching family and NB, with emphasis on the mother. They mentioned the CM as an assistance technology, to favor the interaction of the mother with the child and to allow ample and intense contact with the opportunity of caresses, manifestation of affection, bringing comfort and well-being to the dyad. They recognized KMC as a DC action, voiced a desire to accomplish it broadly, but indicated the inadequacy of physical space as a restrictive factor to their practice. In any case, there was a nurse who assumed that it was not usual to offer the KMC to the family, a fact observed at the moments of observation of this research. It should be noted that, despite the nurses' mention of the method, the term more consistent with what was done would be only the kangaroo positioning, since they did not perform all the recommended steps.

They justified the impossibility of carrying out this practice and the risk of investing in the $\mathrm{KMC}$, since they would have to assume all the intercurrences that might occur, especially in the case of the medical profession. In the registries of the records analyzed, the practice was little mentioned.

Oh, the Kangaroo Mother Care is good, right, [...] caressing too, because it is inside the incubator, or just picking up the moments of bathing, handling ... It's nice, right? We like affection and they too, it's not different. (N9)
Sometimes a more structured family is educated, you know, and ends up asking, then we try, give a push in the incubator, put an armchair and try to do, but it is very little, now the lay family does not ask, is afraid and people also does not end up offering, so I think it is very flawed, the contact with the family is very little. (N10)

They reported a desire to allow family presence in a comprehensive manner and affirmed that nurses were a central and strategic professional to guarantee and qualify the presence of parents in the NICU.

The comprehensive presence of the family member is important, [silence] but, our ICU does not, so you would have to change the structure of the ICU, it cannot be salon style, it needs to be individual and that makes it more expensive. But it's a very good result for NB, because I already had this experience of the father and the mother inside the ICU, they are calmer. [...] nurses can allow and help the mother and father to be more at ICU, but any problem with this the nurses carry it on their back. It's complicated. (N4)

Sometimes for you to put a baby on your lap is a fight, you have to stay asking for authorization, you know?! It is not every doctor who is accessible, who authorizes. (N2)

The observations revealed little comfort of some nurses in the interactions with the family, especially in front of the informational demand, questions about procedures performed and hospital discharge anxiety. The communication occurred through punctual responses, with paralanguage contrary to the interaction with the family member.

As a consequence, in the observations, it was noticed that the nurse had a punctual and restricted approach with the family at the moments of visit, not investing in approximation or greater involvement.

There is a father who looks anxious, looking for a look. He looks at the NB without touching and with interlaced fingers moves the body discreetly back and forth, holding in place. The father looks at me and nods, calling me to go to him. At this moment, I notice the nurse, who is directed to the father informing that the doctor will soon pass from bed to bed giving explanations. Another parent takes advantage of the situation and questions it about the son's saturation and heart rate values, and the nurse simply explains it by saying that it is a function of the baby's clinical condition and repositions it. He returns to the place where he was and adopts an attitude that favors little exchange of looks with parents present in the NICU. (field note - observation)

In contrast, they demonstrated favorable interactional abilities in relation to the family in the practice of breastfeeding. In one institution, the mother was allowed to breastfeed for a differentiated stay in the unit (right to be present all day depending on the clinical conditions of NB), and the nurse referred to develop breastfeeding promotion actions, seeking to approach the mother, providing guidance and trying to empower it to practice.

I noticed that the daytime presence of mothers who are breastfeeding their children are allowed, for they arrive in 
the morning and remain until twenty-one hours. Relational processes between professional and family seem to be more intense, intimate and constant. They talk openly with the professionals and receive help in front of the need. This relationship is different from those in which the mother is present only at visiting times, which are punctual and distant. (field note - observation)

It should be noted that in the institution that did not adopt the Breastfeeding (BF) stimulus, the nurses recognized the actions aimed at the promotion of BF as incipient. In this sense, they had the belief that the restriction of the parents' living together with the NB in the NICU made it difficult for the process of attachment and the autonomy of the family to take care of and unfold in the process of breastfeeding.

So how come you bring the mother to the care of the baby if she does not stay here to see, if she does not know what it is [...] right? So I think one of these things is. I think I encourage breastfeeding, I think that here is still a business that is still slow, for example, the babies I saw that went to the nursery, only one I saw sucking on the mother here, the others I saw no attempt to put. But the visiting time for me is the most glaring. So will the family approach the care, find out and create a greater, more efficient bond? (N5)

Despite the speeches, in the relational processes observed that involved the $\mathrm{BF}$, the verbalized mother dissatisfactions were disregarded in their particularity and there were no conversations between the mother and the receptive professional to the opinions of the mother.

I notice that the baby insists on just grabbing the nipple. The nurse removes it and waits a little before trying again. The infant uses cheek-wrenching strategy to boost sucking when the baby picks up correctly for seconds. At no point did the nurse offer help or questioned maternal preferences. (field note - observation)

\section{DISCUSSION}

The dissonance between discourse and action is evidenced in the findings, since the nurse knows about the DC, without the full demonstration of this knowledge in the doing of the same ones. In view of this, it is important initially to highlight two aspects: power relations among professionals, in the hospital institution itself; and protocols and care routines.

The results of this study suggest that issues inherent in power relations between nurses and physicians, and nurses and managers seem to restrict autonomy, freedom and the struggle for change within the DC, even in the face of informed knowledge about their relevance. The meaning of being difficult to grasp the power of doctors and managers contributed to the nurses of this study to leave their valuation assistance of the DC to be marked by the permission and collaboration or not of the mentioned actors.

The biomedical model, as hegemonic and inspiring of the hospital care philosophies, has limits in terms of assistance, and it is noted that Nursing is linked to the subjection that this model can determine in the hospital context, which often distances from the heart of their work: human care ${ }^{(13)}$. Bio power may be present in the health work process described above, permeated by relational tensions. These relationships end up delegitimizing the nurse's knowledge and practice ${ }^{(14)}$. Linked to this, Nursing still has difficulty recognizing itself as a profession that has its own scientific knowledge and a specific care object, an aspect that contributes to its social devaluation, making the profession not be perceived and recognized ${ }^{(13)}$.

In spite of this, in the first category, it is well known that the nurse tries to consider care directed to the adequate accommodation of NB in the bed, as well as, more timidly, questions related to noise, lightness and excessive handling. In fact, these are goals that are pertinent to a practice aligned with the philosophy of the DC and must be a commitment of the entire NICU care team, when the existence of protocols and care routines can collaborate.

A national study endorsed the care protocol regarding the adoption of NB sleep schedules in NICU, with maximum handling minimization, since the practice generated an increase in the total NB sleep time, especially in quiet sleep, as opposed to the care periods in NICU, which is not adopted the same ${ }^{(2)}$. Articulating sleep and other issues, it is highlighted in the literature that the CM contributes with hours of sleep ${ }^{(15-16)}$, as well as enlarges the interactions between the NB and the one that is in contact with skin and skin with it and maintains the same in positioning physiologically adequate ${ }^{(16)}$. The articulation between sleep and adequate positioning is highlighted in a recent Chinese study ${ }^{(17)}$. In terms of positioning, a Brazilian study discloses a validated NB positioning protocol and reinforces that it is extremely important to take the positioning questions, in the reflections about Nursing care practices in $\mathrm{NICU}^{(18)}$.

Another care protocol aligned with the DC philosophy is the use of tissue over incubators with a view to reducing the incidence of light and the level of sound pressure offered to NB. A study that appreciated this articulated question to the sound emitted by the oximeter and infusion pump recommends the use of the tissue, but emphasizes that its use without removal of the equipment placed on the dome promotes more intense levels of noise ${ }^{(19)}$. The results presented here show the permanence of the habit of making use of the dome as support of objects.

Directing the discussion on the insertion and participation of the family in NICU care, the nurses recognized deficiencies in their care. The family was mentioned as fundamental for the development of the NB, especially for representing affective welcome to him. They claim to be in favor of their stay in the NICU, especially the mother who breastfeeds. However, it was notorious and verbalized that the stay of the parents in the NICU generates discomfort and annoyance to the nurses. They feel unfit to deal with the family, especially with the information demand that is constantly demanded. Before it, the manifest attitude was to avoid them and / or not to favor interactions that effected dialogues. These findings are in line with a study on family-centered care ${ }^{(20)}$, where nurses reveal knowledge about aspects related to this care, but point out that this practice is not fully incorporated into the routine; emphasize how 
insufficient collaboration and interprofessional support for it, lack of Permanent Education programs that address the theme and cultural dissonances.

A study focused on the maternal experience in the NICU revealed that mothers have a health professional in their care who is directed to her to transmit information, to reinforce her command and to explain the need for obedience, for example, to avoid dialogue. In view of this, mothers feel they are expecting the child's care and experience insufficient professional support ${ }^{(21)}$. By denying participation in decision-making steps towards their child, mothers experience feelings of coercion, non-belonging to the child and the NICU as an environment of professional ownership. In addition, they feel fear as they are held responsible for their child's care and must be vigilant about their health status ${ }^{(22)}$.

The recommendation to carry out the Nursing Care Systematization (SAE- Sistematização da Assistência de Enfermagem) aims at individualized, human and pertinent care to the needs of each patient ${ }^{(7)}$. Nursing history, diagnoses and prescriptions did not translate this effort, and one can ask why it leads to this. A descriptive study with a qualitative and documentary approach, on the agreement between Nursing prescriptions and the patient care needs, concluded that many Brazilian institutions, like the one in this study, have been using the electronic documentation to register care for patients. However, it emphasizes that although the tool favors the direction of the work, it is frequent to reproduce / copy the previous prescriptions, suggesting uncritical reproducibility of the same, with partially contemplated and outdated care needs. This reality implies in not achieving the quality of care $^{(22)}$.

The meaning of the nurse being compromised with the DC, portrayed in the interviews, could sustain disruption actions with the replication of the suggestions of the computerized system in the SAE implementation. However, there is another meaning that prevails over this and still restricts it.

Taking the theoretical referential of this study, the one revealed here connects with the conversation internalized in the "self" and directs to the act. Nurses' interactions with the physician, institutional norms and guidelines obfuscate the effects of interactions with NB and his family, and of the nurse himself, his values and principles, including those related to the DC. That is, the "me", analytical phase that ponders the other relational, when interacting with the analytic phase " $\mathrm{I}$ ", that which takes itself as the main reference and has an impulsive character, makes arise and maintains a "self" strongly anchored in the doctor's attention and institutional guidelines, equally impregnated with biological values. The strength of interaction with these others makes subsuming the effects of interactions with other social elements and that could have a role of intending such manifestation.

It is noticed that the nurses know the main beacons of the DC, but they do not bring them with fullness in their attitudes, much less in their registries. The effectiveness of care can be hampered by the scarcity of resources, work philosophy and lack of awareness among professionals, coupled with the absence of reflections on the paradigms of health care. It is essential to go beyond the biologically sick body of NB and see it in its biological, psychological, social and spiritual dimensions, which implies that the professional is responsible to commit to holistic care. In this context, it is relevant to renew the reflections about the professional role and social implications, including those related to child development. There is a need for changes in the nurse's attitude regarding the incorporation of the DC to their professional practice, since they are related to behavioral transformation.

The situational diagnosis leaves the need for Permanent Education (PE) with nurses in the direction of a critical and dialogic educational process, strengthening nurses' autonomy for care delivery and allowing it to have space to explore the micro and macrossocial determinants that are implicated in this issue here diagnosed as of incongruence between the knowledge and the do before the DC, in the assistance of these nurses of NICU.

\section{Study limitations}

This is a study limited to NICU nurses from a city in São Paulo countryside.

\section{Contributions to Nursing}

It allowed elucidating how the nurse incorporates the DC in its assistance, pointing out possibilities of interventions to qualify the assistance in the NICU, with developments within reach of integral and human care. In addition, it brings in its core the need to maintain and invest in the exploration of the nurse's autonomy in the hospital structure, with attention to the relationship with physicians and their symbolism.

\section{FINAL CONSIDERATIONS}

The use of data triangulation was a potential resource for apprehending nursing care in the NICU, because it favors evidence related to knowledge and attitudes. It allowed to affirm that nurses have knowledge and recognition of the importance of the Developmental Care for the quality of care, but they do not show correspondence between these and the executed/ registered (attitudinal elements), in almost all dimensions.

The highest correlation between knowledge and attitudinal behavior was present in the care offered in view of the risk or duration of pain. In the other dimensions of the DC mentioned or brought in their practice (family, environment, handling, BF/ nutrition), a lack of correlation between doing and knowing was diagnosed.

Faced with such a diagnosis, the study recommends Permanent Education in the direction of stimulate reflections about the practice in what relates to the DC and its registration, besides fostering criticality and the perception of the executed. Such a path has the potential to promote new meanings and to transform NICU's nursing care in this philosophy of care.

It is suggested that analyzing the meaning attributed by nurses to SAE would be a relevant step to qualify Nursing care and its registration, including seeking the articulation that identifies the recommendations of the DC. In addition, the essentiality of commitments in involving NICU professionals to think protocols and care routines attuned to Developmental Care. 


\section{REFERENCES}

1. Brasil. Dados do Sistema Único de Saúde-DATASUS. Informações em Saúde. Nascidos vivos: Brasil[Internet]. Brasília; 2014[cited 2018 Jun 15]. Available from: http://tabnet.datasus.gov.br/cgi/tabcgi.exe?sinasc/cnv/nvuf.def

2. Orsi KCSC, Llaguno NS, Avelar AFM, Tsunemi MH, Pedreira MLG, Sato MH, et al. Effect of reducing sensory and environmental stimuli during hospitalized premature infant sleep. Rev Esc Enferm USP[Internet]. 2015[cited 2017 Oct 09];49(4):549-55. Available from: http://www.scielo.br/pdf/reeusp/v49n4/0080-6234-reeusp-49-04-0550.pdf

3. Reis AT, Benevides MRR. Cuidados voltados para o desenvolvimento na clientela neonatal cirúrgica: contribuições para a enfermagem. Rev Ciênc Med[Internet]. 2015[cited 2017 Oct 09];24(3):131-8. Available from: http://periodicos.puc-campinas.edu.br/seer/index. php/cienciasmedicas/article/view/2646/2318

4. Abdeyazdan Z, Ghasemi S, Marofi M, Berjis N. Motor responses and weight gaining in neonates through use of two methods of earmuff and receiving silence in NICU. Sci World J[Internet]. 2014[cited 2017 Oct 09];2014:1-5. Available from: https://www. hindawi.com/journals/tswj/2014/864780/cta/

5. Gaspardo CM, Martinez FE, Linhares MB. Cuidado ao desenvolvimento: intervenções de proteção ao desenvolvimento inicial de recém-nascidos pré-termo. Rev Paul Pediatr[Internet]. 2010[cited 2018 Jun 15];28(1):77-85. Available from: http://www.scielo.br/ $\mathrm{pdf} / \mathrm{rpp} / \mathrm{v} 28 \mathrm{n} 1 / \mathrm{v} 28 \mathrm{n} 1 \mathrm{a} 13 . \mathrm{pdf}$

6. Als H. Toward a synactive theory of development: promise for the assessment and support of infant individuality. Infant Mental Health J[Internet]. 1982[cited 2017 Oct 09];3(4):229-43. Available from: https://doi.org/10.1002/1097-0355(198224)3:4<229::AID-IMHJ2280030405> 3.0.CO;2-H

7. Souza JM, Veríssimo MLOR. Child development in the NANDA-I and international classification for nursing practices nursing classifications. Int J Nurs Knowl[Internet]. 2013[cited 2017 Oct 09];24(1):44-8. Available from: http://onlinelibrary.wiley.com/ doi/10.1111/j.2047-3095.2012.01228.x/pdf

8. Brasil. Ministério da Saúde. Agenda Nacional de Prioridades de Pesquisa em Saúde. Série B. Textos Básicos em Saúde. 2 ed. Brasília, 2011 $2011 b$.

9. Charon JM. Symbolic interactionism: an introduction, an interpretation, an integration. 10 ed. Boston: Prentice Hall; 2010.

10. Lisanti AJ, Cribben J, Connock EM, Medoff-Cooper B. developmental care rounds: an interdisciplinary approach to support developmentally appropriate care of infants born with complex congenital heart disease. Clin Perinatol[Internet]. 2016 [cited 2018 Jun 17];43:147-56. Available from: https://doi.org/10.1016/j.clp.2015.11.010

11. Brasil. Dados do Sistema Único de Saúde-DATASUS. Informações de saúde, indicadores de saúde: Nascidos Vivos São Paulo[Internet]. 2015[cited 2017 Oct 09]. Available from:http://tabnet.datasus.gov.br/cgi/tabcgi.exe?sinasc/cnv/nvsp.def

12. Bardin L. Análise de conteúdo. São Paulo: Edições 70; 2011.

13. Lessa ABSL, Araújo CNV. Brazilian nursing: a reflection about political activity. Rev Min Enferm[Internet]. 2013 [cited 2017 Oct 09];17(2):481-7. Available from: http://www.reme.org.br/artigo/detalhes/664

14. Silva EM, Moreira MCN. Health team: negotiations and limits of autonomy, belonging and the acknowledgement of others. Ciênc Saúde Colet[Internet]. 2015[cited 2017 Oct 09];20(10):3033-42. Available from: http://www.scielo.br/pdf/csc/v20n10/en_14138123-csc-20-10-3033.pdf

15. Bastani F, Rajai N, Farsi Z, Als H. The effects of kangaroo care on the sleep and wake states of preterm infants. J Nurs Res[Internet]. 2017[cited 2018 Mar 25];25(3):231-9. Available from: https://www.ncbi.nlm.nih.gov/pubmed/28481819

16. Buil A, Carchon I, Apter G, Laborne FX, Granier M, Devouche E. Kangaroo supported diagonal flexion positioning: new insights into skin-to-skin contact for communication between mothers and very preterm infants. Arch Pediatr[Internet]. 2016[cited 2018 Mar 25];23(9):913-20. Available from: https://www.ncbi.nlm.nih.gov/pubmed/27388909

17. Liaw JJ, Yang L, Lo C, Yuh YS, Fan HC, Chang YC, et al. Caregiving and positioning effects on preterm infant states over 24 hours in a neonatal unit in Taiwan. Res Nurs Health[Internet]. 2012[cited 2018 Mar 24];35:132-45. Available from: http://onlinelibrary. wiley.com/doi/10.1002/nur.21458/epdf

18. Toso BRGO, Viera CS, Valter JM, Delatore S, Barreto GMS. Validation of newborn positioning protocol in Intensive Care Unit. Rev Bras Enferm[Internet]. 2015[cited 2018 Mar 24];68(6):835-41. Available from: http://www.scielo.br/pdf/reben/v68n6/en_00347167-reben-68-06-1147.pdf

19. Miranda AM, Scochi CGS, Santos CB, Zamberlan NE, Fonseca LMM, Leite AM. The use of incubator covers: repercussion on noise levels. Cienc Cuid Saude[Internet]. 2016[cited 2018 Marc 25];15(1):19-26. Available from: http://periodicos.uem.br/ojs/index.php/ CiencCuidSaude/article/view/24407/16965

20. Balbino FS, Balieiro MMFG, Mandetta MA. Measurement of Family-centered care perception and parental stress in a neonatal unit. Rev Latino-Am Enfermagem[Internet]. 2016[cited 2017 Oct 09];24e2753. Available from: http://www.scielo.br/pdf/rlae/ v24/0104-1169-rlae-24-02753.pdf

21. Wernet M, Ayres JRCM, Viera CS, Leite AM, Mello DF. Mother recognition in the Neonatal Intensive Care Unit. Rev Bras Enferm[Internet]. 2015[cited 2017 Oct 09];68(2):228-34. Available from: http://www.scielo.br/pdf/reben/v68n2/en_0034-7167-reben-68-02-0228.pdf 
22. Custodio N, Marski BSL, Abreu FCP, Mello DF, Wernet M. Interactions between health personnel and mothers of preterms: influences on maternal care. Rev Enferm UERJ[Internet]. 2016[cited 2017 Oct 09];24(1):e11659. Available from: http://www.e-publicacoes. uerj.br/index.php/enfermagemuerj/article/view/11659/17858 